\title{
KELAYAKAN USAHA AGRIBISNIS AYAM RAS PEDAGING DI KABUPATEN LAMONGAN
}

\author{
NOVI ITSNA HIDAYATI \\ Staf Pengajar Fakultas Pertanian Universitas Yudharta Pasuruan
}

\begin{abstract}
Propinsi Jawa Timur merupakan salah satu propinsi yang memiliki jumlah penduduk yang lebih dari 4 juta jiwa, juga merupakan daerah yang cukup potensial sebagai tempat pengembangan ayam ras pedaging dalam rangka pemenuhan kebutuhan protein hewani serta peningkatan pendapatan masyarakat. Pada tahun 2001, yaitu 4 tahun setelah terjadinya krisis ekonomi dan moneter sampai tahun 2002, masyarakat yang mengelola usaha peternakan rakyat di Jawa Timur masih mendapatkan keuntungan yang cukup baik. Akan tetapi sejak tahun 2005, setelah terjadinya wabah flu burung, usaha peternakan ayam ras pedaging mengalami permasalahan yang mengancam keberlanjutannya. Hal ini disebabkan karena antar produksi ayam ras pedaging dan konsumsi daging ayam ras pedaging yang mengalami penurunan yang sangat tajam. Tujuan dari penelitian ini adalah : 1) mengkaji kelayakan usaha agribisnis ayam ras pedaging pola kemitraan di Kabupaten Lamongan dari aspek financial; 2) menentukan skala usaha yang layak diusahakan Usaha agribisnis ayam ras pedaging pola kemitraan memenuhi kriteria kelayakan. Hal ini dapat dilihat dari Payback Period selam 4 tahun 11 bulan, Break Even Point sebanyak 1.888 ekor atau setara dengan Rp.40..929.250, NPV positif sebesar Rp.59.224.851 dan IRR sebesar 23,58\%. Semakin besar skala usaha (volume pemeliharaan) ayam, keuntungan bersih yang diterima peternak semakin besar. Analisis sensitivitas dengan kenaikan biaya produksi 2,5\% disertai penurunan pendapatan 2,5\% memberikan nilai NPV positif Rp.21.468.025 dengan IRR sebesar $16,79 \%$. Analisis sensivitas skala usaha dengan mempergunakan metode simulasi rumusrumus BEP menunjukkan hal yang paling mungkin dilakukan oleh peternak dalam meningkatkan keuntungan dari kondisi yang sedang terjadi di lapangan adalah dengan meningkatkan volume penjualan, sehingga peternak mendapatkan nilai tambah pendapatan yang optimal.
\end{abstract}

Kata kunci : Kelayakan Usaha, Ayam Ras, Lamongan 